\title{
Teacher Educators’ Understanding of Their Language-Oriented Development in Content-Based Classroom Interaction
}

\author{
Fenna Swart ${ }^{1, *}$, Jeroen Onstenk ${ }^{2}$, Dubravka Knèzic ${ }^{3}$ \& Rick de Graaff ${ }^{4}$ \\ ${ }^{1}$ Inholland University of Applied Sciences and Utrecht University, 1087 JC Amsterdam, Netherlands \\ ${ }^{2}$ School of Education, Inholland University of Applied Sciences, 1098BD Amsterdam, Netherlands \\ ${ }^{3}$ Faculty of Education, University of Applied Sciences Amsterdam, 1000 BA Amsterdam, Netherlands \\ ${ }^{4}$ Utrecht University, 3512 JK Utrecht, Netherlands \\ *Correspondence: Maria Austriastraat 6421087 JC Amsterdam, Netherlands. Tel: 31-6-1527-9903. E-mail: \\ fennaswart25@gmail.com
}

The researchers have neither financial interest in nor have received benefits from direct applications of this research.

Received: March 11, 2018

doi:10.5430/wje.v8n2p95

\author{
Accepted: April 2, $2018 \quad$ Online Published: April 12, 2018 \\ URL: https://doi.org/10.5430/wje.v8n2p95
}

\begin{abstract}
Many studies have suggested that personal practical knowledge is essential for professional development. Recently, there has been growing recognition of the importance of teacher educators' personal practical knowledge of 'language' for student learning development. However, the need for teacher educators to first understand their own language-oriented development in content-based classroom interaction has not received as much emphasis. The current intervention study investigates how eleven experienced teacher educators understand their language-oriented development through the control of task difficulty, small-group instruction and directed response questioning. Data were examined by conducting content and constant comparison analyses. The results showed that the intervention affected the educators' language-oriented development, which in turn affected their awareness and decisions made to improve their methods of initiation and response during classroom interaction. The results call for more concrete ways to expend teacher educators' practical knowledge of language to further develop and enhance their language-oriented teaching performance in content-based classroom interaction.
\end{abstract}

Keywords: professional development; teacher educator; reflective practice, subject teaching, classroom interaction

\section{Introduction}

Because this study addresses teacher educators' language-oriented development, it must be clarified what is meant by language. The concept of 'language' has adopted a range of meanings over the past few decades, varying from a grammar-oriented to a more functional and dynamic view. In the current study, language was conceptualized as 'language-in-use' (Lacombe, 2014) within the social constructionist tradition based on various fundamental developments in socially situated interactions (Vygostki, 1962, 1987, Wertch, 1979; Mercer, 1995, 2008; Wegerif, Boero, Andriessen and Forman, 2009; Hajer, 2000; Panday, Hajer and Beijer, 2007).

From a socio-cultural perspective, starting with Vygotski (1962), 'language' was first referred to as the 'functional dynamics of dialogue'. Ten years later, the term 'language' was replaced by 'speech' (Wertch, 1979) to emphasize the focus on the 'dynamic process of communication'. In this context, more recently, Mercer (2008) argued for the use of 'talk', revisiting sociocultural research on 'classroom talk, interaction, dialogue and discourse'. However, because 'talk' was also associated with unilateral ways to transfer information, rather than the exchange of information through two-way communication, as intended within socially situated interactions, Wegerif (2009) replaced 'talk' with 'dialogic' to emphasize the effectiveness of 'dialogic classroom talk' compared to the monological approaches that still appeared to be dominant in many classrooms (Boyd and Markarian, 2011; Swart et al., $2017 \mathrm{a}, \mathrm{b}$ ). As a result, along with a changing orientation toward knowledge and language (Wells, 2006), there was a growing body of literature on dialogical education and classroom interaction.

In this context, much evidence has indicated the supporting and substantive potential of language within subject 
teaching, ranging from various studies of 'dialogic oriented' pedagogy (Skidmore, 2000) and research (Wells, 2001) to studies of content-based language instruction (Brinton, Snow and Wesche, 2003; Echevarria, Short and Powers, 2008; Law, Reilly and Snow, 2013). The latter area was formerly drawn from research on class management and based on instructional theories (Hoy and Weinstein, 2006) and interventional studies of language-oriented pedagogy (Hajer, 2004). The focus on content- and language-integrated teaching originated from a dually focused educational approach in which the learning of both language and content was accomplished 'with and through a foreign language' (Eurydice, 2006, p. 8; Coyle, Hood and Marsh, 2010; Nikula, Dalton-Puffer, Llinares and Lorenzo, 2016). Research that examined overall practicability was generally positive, suggesting that teaching that was attentive to both language and content was more effective than that focused exclusively on content (Lyster, 2007; Norris \& Ortega, 2000; Swain, 2000). This effectiveness was particularly true when regulated and subject-specific input was provided alongside task-oriented language in conversation and corrective feedback focusing on both content and language (Valeo, 2013).

Recently, language-oriented pedagogies have become a major topic in higher education for several reasons, most importantly because of the socially proposed requirements that teachers should be able to cope with the increasing cultural and linguistic diversity in the classroom (Den Brok, van Eerde and Hajer, 2010). In addition, one study showed that uncertainties surrounding language policy and related pedagogies led not only to an increase in language problems but also to problems with teaching and student learning itself and, thus, problems with students' academic success (Herelixka \& Verhulst, 2014).

From these developments, the need arose for greater language understanding and development among teachers, specific regarding the conceptual and technical demands of their content-based classroom interaction (Dalton-Puffer and Smit, 2013). As a result, more attention was devoted to ongoing language development, including forms of contingent and communicative teaching, alongside the existing regulatory behavioral characteristics of classroom interaction. For example, in a model of classroom interaction and teachers' self-assessment, teacher strategies such as diagnosis and language contingency were examined (Ruiz-Primo and Furtak, 2006, 2007), referring to the regulated support that a teacher provides through interaction (Broza and Kolikant, 2015). In the research by Ruiz-Primo and Furtak (2006), cycles of contingent teaching, for example, appeared far less frequently than unfinished (non-contingent) cycles. This finding was confirmed by other studies that showed an absence of a common problem definitions or diagnosis initiated by teachers during observed teacher-student interactions (Elbers, Hajer, Jonkers, Koole, and Prenger, 2008; Lockhorst, van Oers, and Wubbels, 2006). Conversely, when teachers stimulated critical thinking and reflection during interactions, supported by language-oriented strategies and adjustments to students' learning needs, student responses were not only more contextual in nature but also characterized by the use of more complex linguistic formulations (Walsh and Knight, 2011, 2016).

Teachers who were able to identify such types of formulations appeared more motivated to support students in developing higher levels of language comprehension in technical terms and subject-related concepts (Saylag, 2014). More specifically, the teacher's (third turn) response was contingent upon the student's (second turn) answer because the teacher's response demonstrated understanding of the student's initial question (Lee, 2007) in a substantial, language-oriented fashion. Nassaji and Wells (2000) specified six practical strategies of a teacher's third turn responses: meta-talk, action, explanation, evaluation, counter-argument and clarification. According to these authors, a teacher who responded from an evaluative mode could assume the role of the 'all-knowing' teacher, serving to 'suppress extended student participation' (Nassaji and Wells (2000, p. 400). Conversely, if the teacher implemented other strategies, such as requesting explanation or meta-talk, students could be expected to self-select contributions because of a shift in 'the role of the primary knower' (p. 400-401) in relation to the students. Recent research has offered an understanding of how teachers' questions function in classroom practice. Based on an international range of studies on 'literacy pedagogy', Wolf, Crosson, and Resnick (2006) concluded that when teachers simply check students' understanding by pursuing closed questions and receiving 'yes' or 'no' answers or frame questions in a way that allows students simply to complete the teacher's thoughts, such strategies do not support students' high-level literacy skills. According to these authors, by contrast, when teachers use questions as a tool for reasoning and stimulate students to rephrase content and to elaborate on the concepts, students' literacy comprehension improves. This finding was further confirmed in the study by Kyriacou and Issitt (2008), who reviewed fifteen studies of talk in mathematics classrooms and found that student results improve when teachers use questions not only to seek the right answers but also to elicit reasoning and explanations. To obtain the best results, teachers must strategically balance 'authoritative' talk, which is typically the dominant form (Scott, 2008), and 'dialogue', which tends to occur less often (Mercer and Howe 2012).

Informed by systemic functional linguistic theory, the literature has identified a variety of teacher talk strategies that 
allow the teacher to guide his or her students into forms of subject-specific engagement (Sharpe, 2008), i.e., commitment to the content matter. For example, in an analysis of two history lessons that occurred at the beginning and end of a first-year module in an Australian high school, several teacher talk strategies were identified, including repeating, rearranging and re-contextualizing teachers' spoken language, which in turn stimulated students' development of language skills and content applicable to a particular subject (Sharpe, 2008).

Regarding this specific focus on language-oriented pedagogies, the literature indicates four important language proficiencies that a teacher should acquire (den Brok, van Eerde and Hajer, 2010): 'awareness of language differences', 'ability to making content intelligible through language', 'opportunity for language production' and 'developing language skills in the content area'. These proficiencies are intended to support student learning through educational strategies, including language-oriented practices.

This study adds to the literature because the functional dynamics and the dynamic and developing processes of teacher educators' classroom interaction are both central to the concept of 'language-oriented development in content-based classroom interaction'. Previous studies have also referred to the concept as 'language-sensitive and interpersonal oriented'-referring to a receptive means of communication — and 'language-oriented and pedagogical'-referring to a productive and goal-oriented means of communication (Swart et al, $2017 \mathrm{a}, \mathrm{b}$ ); these types of communication can be implemented separately or incorporated into teacher educators' content-based classroom interaction. In other words, teacher educators need to be both sensitive and facilitating to provide accessibility and support (Moy, Renshaw and Davids, 2014). In this context, an important area for study is that the teacher educator is essentially an active listener (Boyd and Markarian, 2011). That is, teacher educators who understand their language-oriented subject teaching better allow themselves to better understand their students by actively listening and encouraging them to articulate what they think and know and thereby to better position themselves as future teachers. Thus, it is reasonable to expect that with the convergence of interpersonal and pedagogically oriented language in subject teaching (Swart et al. 2017, a b), teacher educators may extend their pedagogies to support and guide learning conversation (Boyd and Galda, 2011) and to conduct knowledgeable interaction in an understanding and informative manner.

Against this background - and consistent with the claim that, in addition to teaching content, the process and functional dynamics also matter and thus influence learning development (Vygotsky, 1962; Wertsch; 1979; Mercer, 2008, 2016) - the present study aims to contribute to the development and empirical validation of teacher educators' language-oriented subject teaching. Based on teacher educators' reflections of their own, regular lessons in response to previously conducted group conversations with peers to conceptualize continuous language development in professional learning and teaching (Swart et al., 2017, b), we established the following research question: How do teacher educators understand their language-oriented development in content-based classroom interaction?

Recently, several studies have indicated that it is of additional value for teacher educators learn to assess their classroom experiences through reflective conversations with others (Putnam \& Borko, 2000). For example, a 'Lesson Study', which was based essentially on merging many premises found within the broader literature on teachers' learning (Bakkenes, Vermunt and Wubbels, 2010) and specifically grounded in intervention research, involved collaborative planning and interaction within professional communities via the self-assessment of lessons (Lieberman and Miller, 2008; McLaughlin and Talbert, 2006). In this context, 'self-assessment' means reflection on one's own lessons to understand what occurred, i.e., what the teacher did and said and how the students responded. Although teaching has generally been considered an action-oriented practice, in the current study, teacher educators were stimulated to develop reflective skills to support their observations of 'what occurred' in their language-oriented actions during class interaction and thereby 'learning to understand' their language-oriented development in pedagogical decisions for future lessons; thus, the approach encourages teacher educators to be flexible in their educational plans while teaching. 


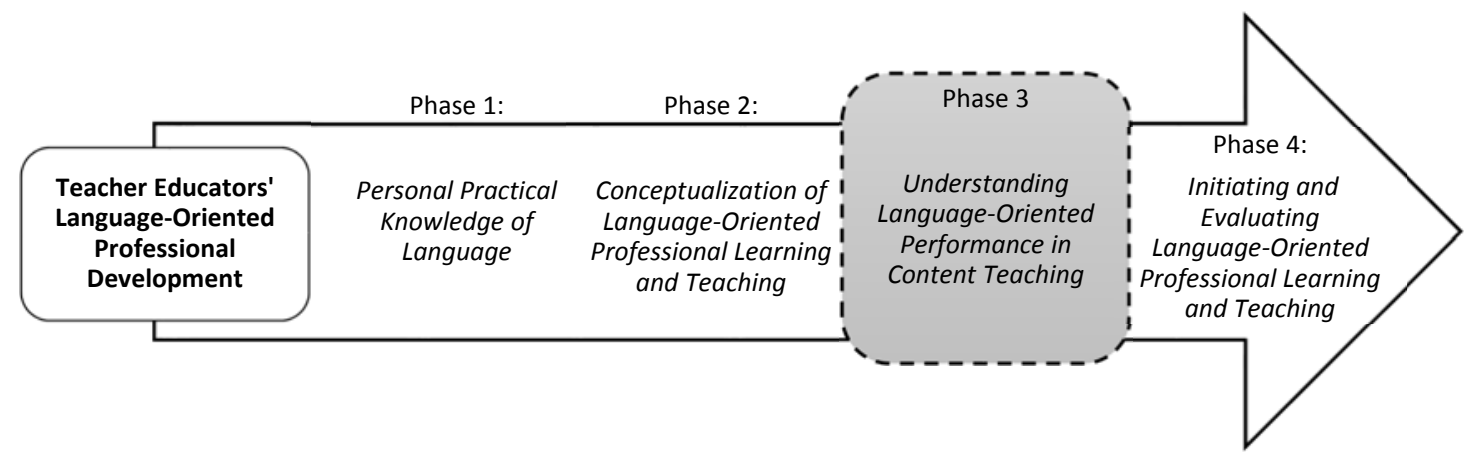

Figure 1. Research Design of Teacher Educators' Language-Oriented Professional Development with the Highlighted Phase (3) of the Current Study

\section{Method}

\subsection{Context and Participants}

The current study was conducted as part of a three-year project of language-oriented professional development with participants from several teacher trainer institutes in the Netherlands (Figure 1, phase 1/4). The focus aimed at the language-oriented development of eleven teacher educators experienced in the sciences and social sciences; these teacher educators received training from three teacher-training institutes and volunteered to participate in stage 3 of the project (Figure 1, stage 3). Convenience sampling was used to select teacher educators based on their participation in the previous two phases (Table 1)

Table 1. Participants

\begin{tabular}{llllll}
\hline Group & $\begin{array}{l}\text { Participan } \\
\text { ts }\end{array}$ & Subject & $\begin{array}{l}\text { Femal } \\
\text { e }\end{array}$ & $\begin{array}{l}\text { Male } \\
\text { Average } \\
\text { work } \\
\text { experience/ } \\
\text { years }\end{array}$ \\
\hline 1 & $3 ;$ & $\begin{array}{l}\text { Social Studies } \\
(3)\end{array}$ & 0 & 3 & 16 \\
2 & $\begin{array}{l}\text { P1, 2, } 3 \\
3 ;\end{array}$ & $\begin{array}{l}\text { Technical studies } \\
(3)\end{array}$ & 0 & 3 & 18 \\
& P4, 5, 6 & & & \\
3 & $5 ;$ & $\begin{array}{l}\text { Mathematics (1) } \\
\text { Geography (1) }\end{array}$ & & 4 & 12 \\
& $\begin{array}{l}\text { P7, 8, 9, } \\
10,11\end{array}$ & $\begin{array}{l}\text { History (1) } \\
\text { Education (1) } \\
\text { Religion (1) }\end{array}$ & & \\
& & & & \\
Totals & 11 & & & & \\
\hline
\end{tabular}

\subsection{Research Design}

We examined teacher educators' understanding through a reflective teacher practice approach in a small-scale intervention study. Because we were initially interested in how teacher educators' practical knowledge of language was related to their language-oriented professional learning goals, we previously reported how teacher educators conceptualized and operationalized these objectives (Swart et al., a,b). In the current study, we examined teacher educators' understanding of their language-oriented development in response to recordings of their regular classes without accompanying instructions. To facilitate the process of 'reflective teacher practice', we used three critical factors for 'improved learning outcomes' (Swanson, Hoskyn and Lee, 1999; Vaughn, Gersten and Chard, 2000): control of task difficulty, small-group instruction and directed response questioning. These factors were previously identified to have the greatest effect on students' learning development, regardless of the model or content of instruction (Swanson et al., 1999). Given the potential of these aspects 'to work in concert' (Vaughn, Gersten and Chard, 2000, p.101), i.e., to collectively reinforce one another, the three factors were applied in the current 
intervention study to stimulate the reflective practice of the teacher educators, regardless of their subject domain.

\subsection{Intervention}

An important objective of professional development is to assess class experiences through reflective practice with others (Putnam \& Borko, 2000). To this end, the intervention consisted of six phases: 1) an introductory meeting focusing on the practical and logistical implementation of the intervention; 2) a video recording of lesson 1 for each participant and the selection of subject-specific interaction excerpts by the participant him/herself; 3) individual reflective interviews about participants' language-oriented development during the just-completed lesson $1 ; 4$ ) individually stimulated recall interviews while participants viewed selected subject-specific interaction excerpts from lesson 1; 5) a video recording of lesson 2 for each participant and the selection of subject-specific interaction excerpts by the participant him/herself; and 6) focus group interviews about the selected excerpts from lesson 2 (see more details in the 'Instruments and Procedure' section). During the third, fourth and sixth phases, participants were asked to evaluate their language-oriented development and substantiate their evaluations with practical examples according to the three-factor structure for 'improved learning outcomes' (Swanson, et al., 1999). This step was based on the expectation that the interviews and evaluations could affect lesson 2 relative to lesson 1 because of a potential increased awareness and understanding of their responses (Table 2).

Table 2. Intervention Set-Up

\begin{tabular}{|c|c|c|c|}
\hline $\begin{array}{l}\text { Data Collection and Stages; (I) a,b,c } \\
\text { Intervention Phases: (S) } 1 / 4\end{array}$ & $\begin{array}{c}\text { Ia. } \\
\text { Reflective }\end{array}$ & $\begin{array}{c}\text { Ib. } \\
\text { Stimulated Recall }\end{array}$ & $\begin{array}{c}\text { Ic. } \\
\text { Focus Groups }\end{array}$ \\
\hline \multicolumn{4}{|l|}{ S1 } \\
\hline \multicolumn{4}{|l|}{ Introductory meeting } \\
\hline \multicolumn{4}{|l|}{ S2 } \\
\hline \multicolumn{4}{|l|}{$\begin{array}{l}\text { Regular class performance, video recording } \\
\text { and selection of interaction excerpts, lesson } 1\end{array}$} \\
\hline S3 & based on just- & & \\
\hline Reflective interviews & $\begin{array}{c}\text { completed lesson } \\
1\end{array}$ & & \\
\hline \multicolumn{4}{|l|}{ S4 } \\
\hline $\begin{array}{l}\text { Stimulated recall interviews while viewing } \\
\text { selected material; interaction excerpts on video } \\
\text { of lesson } 1\end{array}$ & & $\begin{array}{l}\text { based on selected and } \\
\text { viewed excerpts of } \\
\text { lesson } 1\end{array}$ & \\
\hline \multicolumn{4}{|l|}{ S5 } \\
\hline \multicolumn{4}{|l|}{$\begin{array}{l}\text { Class performance, video recording and } \\
\text { selection of interaction excerpts, lesson } 2\end{array}$} \\
\hline S6 & & & based on selected \\
\hline Focus group interviews & & & $\begin{array}{l}\text { and viewed } \\
\text { excerpts of lesson } \\
2\end{array}$ \\
\hline
\end{tabular}

\subsection{Instruments and Procedure}

Participants' understanding was examined with three instruments based on the three-factor structure for 'improved learning outcomes' (Swanson et al., 1999) and existing methods for collecting information about teacher educators' practical knowledge of language (Swart et al., 2017 a), related conceptualizations (Swart et al., 2017b) and validated observation instruments. This approach was based on the works of Rimm-Kaufman, Storm, Sawyer, Pianta and LaParo (2006): 1) Semi-structured reflective interviews were conducted to determine participants' understanding and evaluations of their language-oriented development in terms of subject, purpose and process, followed by their selection of noted interactive encounters and their evaluation of the entire interactive performance immediately after lesson 1. 2) Stimulated recall interviews were conducted to stimulate participants to think aloud and to explore their views on aspects of their language-oriented process while viewing the selected video excerpts one week after lesson 1. The following aspects (Swart et al., 2017b) were related to process: the 'starting and finishing point', 'contingency on student language', 'language-oriented feedback and support', 'use of question types', 'use of subject-specific key concepts', 'use of verbal and nonverbal modeling' and 'potential for improvement'. 3) Focus group interviews were conducted to encourage participants to share with professional colleagues their understanding of language-oriented 
development in terms of subject, purpose and process and their evaluation of the entire interactive performance after lesson 2.

The selection of video excerpts and the interviews after lessons 1 and 2 were deliberately used for data collection and intervention but were not presented as such to the participants; prior to lesson 2, participants were given no instruction to act or respond in a language-oriented manner, but attention was paid to whether they deliberately acted or did not act according to their insights from the interviews.

Triangulation of methods was sought by combining the results gathered using different instruments (Smaling, 1994). In this manner, triangulation was not a matter of determining whether data analysis from each of the three instruments would lead to similar outcomes; rather, the data were combined to develop a comprehensive view of teachers' practical knowledge (Meijer, Verloop and Beijaard, 2002) with regard to their language-oriented development in classroom interaction.

In recording classroom observations and the subsequent selection of excerpts, a combination of dual-view technology and recording was applied within the video-based professional learning platform 'IRIS Connect LTD' (WEE/AA1796TU, Brighton). Each participant received a personal password-protected account that allowed him or her to record, control and share his or her teaching practice and learning experiences from a secure cloud-based platform. During the intervention, participants' classes were recorded by two small iPads directed at the teacher and students. Participants were given a neck strap featuring a magnet and a microphone. Thus, all their movements and classroom interactions were tracked in a discrete and silent manner and recorded from dual points of view.

Reflective Interviews (S1):

D1: Subject, purpose, process

of language-oriented development

(reflections)

Stimulated Recall Interviews (S2)

D2: Practical aspects

of language-oriented development

(self-assessments and reflections)

Focus Group Interviews (S3)

D3: Subject, purpose, process

of language-oriented development

(reflections)
Self-assessment, lesson 1

prior to (S1) and after (S2)

reviewing selected excerpts

of lesson 1 on video

\section{Self-assessment, lesson 2}

after reviewing selected excerpts

of lesson 2 on video

Figure 2. Data Collection, Stages (S1, 2, 3) and Datasets (D1, 2, 3)

\subsection{Analysis}

The datasets, which consisted of the reports and transcriptions of the reflective (1), stimulated recall (2) and focus group interviews (3), were first examined using constant comparison analysis (Glaser, 1965; Ryan and Bernard, 2000). This type of analysis was used to search for indications and clarifications of behavior during the selected excerpts over time, giving rise to descriptive categories (Lincoln \& Guba, 1985). The accumulated categories were subsequently analyzed with the aid of Atlas Ti, using content analysis to gain explanatory information (Miles and Huberman, 1994). In this study, content analysis was considered an alternative to the statistical approach to qualitative data to obtain numerical data from word-based data. As such, we were able to describe the qualified occurrence and importance of topics. This analysis was performed by systematically comparing the categories and by 
using participants' perceptions as a frame of reference (Malterud, 2001). The final summation of data allowed us to identify the main categories for analysis (Atkinson \& Hammersley, 1994) (Table 4-7).

The datasets (D1, 2, 3) were each analyzed separately after all rounds (S1, 2, 3) were completed (Figure 2). The analysis was performed deductively (Leech and Onwuegbuzie, 2007). That is, the main codes and sub-codes were identified prior to analysis based on the topic structure used in the intervention (Figure 2). The following main codes were used: subject (SU), purpose (PU), process (PR), assessment (AS), and evaluation (EV) (Ruiz-Primo and Furtak, 2006, 2007). The sub-codes were as follows: starting point and completion (sc), contingency on student language (cl), language-oriented feedback and support (fs), conscious use of question types (qt), use of subject-specific key concepts (ss), use of verbal and nonverbal modeling (mo), and potential for improvement (im) (Swart et al., 2017b; Rimm-Kaufman et al., 2006) (Table 3). The reports and transcriptions of the reflective interviews were then analyzed by assigning the pre-selected codes to each comment made (Lincoln \& Guba, 1985). A second researcher repeated the process to cross-check the allocation process, which was then discussed until agreement was reached. Through constant comparison, which involved exploring the connections between codes and performance, categories of reflection and self-assessment were further refined by analyzing the remaining reports and transcripts of the stimulated recall and focus group interviews using the agreed-upon procedure. Variation was examined by considering the differences and similarities among individual participants in each dataset. This analytical approach aimed to guarantee a basis for a comprehensive description of the group and the individual participants. To determine the validity and accuracy of the descriptions and to explain the themes generated from the data, the resulting themes were clustered based on similarity and presented to participants for a member check (Maxwell, 1992).

Table 3. Instrumental Phases, Codes and Topics

(Pre-selected) Topics, Codes; Main and Sub and (Analysis) Instrumental Stages

(S); Reflective, S2, Stimulated Recall, and S3 Focus Group Interviews

\begin{tabular}{llll} 
Instrument/S & Codes & Sub-codes & Topics \\
$1,2,3$ & SU & & SUBJECT \\
$1,2,3$ & PU & & PURPOSE \\
$1,2,3$ & PR & & PROCESS \\
2 & & sc & starting point and completion \\
2 & & cl & contingency on student language \\
2 & & qt & conscious use of question types \\
2 & & ss & subject-specific key concepts \\
2 & & fs & language-oriented feedback and support \\
2 & & mo & role model verbally/nonverbally \\
2 & & im & potential for improving LOP \\
$1,2,3$ & EV & & EVALUATION \\
\hline
\end{tabular}

\section{Results}

We aimed to explore the understanding of teacher educators' language-oriented development, given that the simultaneous development of language and content involves reflection $\mathrm{n}$ the use and evaluation of language in interactions during subject-specific teaching. To that end, by analyzing participants' self-selected excerpts of video-recorded language-oriented responses through self-assessment by the individual and the group, we explored the qualitatively different ways in which these educators taught. Based on this exploration, we identified the subject, purpose and process of teacher educators' language-oriented development, in addition to their evaluation of their entire performance in lessons 1 and 2. In this section, the results are presented (Tables 4 and 5) as follows: 1 . reflective interviews; 2. stimulated recall interviews; 3. comparison of reflective and stimulated recall interviews; and 4 . focus groups. 
Table 4. Results of the Reflective and Stimulated Recall Interviews

\begin{tabular}{|c|c|c|c|c|}
\hline \multirow[t]{2}{*}{ Topics } & \multicolumn{4}{|c|}{ Results (Most Frequently Mentioned out of 11 Participants) } \\
\hline & Reflective Interviews & & Stimulated Recall Interviews & \\
\hline & LESSON 1 & & LESSON 1 & \\
\hline \multirow[t]{2}{*}{ SUBJECT } & Subject-specific content & 9 & Subject-specific content & 1 \\
\hline & & & & 0 \\
\hline \multirow[t]{3}{*}{ PURPOSE } & $\begin{array}{l}\text { Clarification of subject-specific } \\
\text { content }\end{array}$ & 11 & Explanation of key terms & 11 \\
\hline & Promoting student understanding & 8 & Achieving subject matter targets & 6 \\
\hline & & & Promoting student understanding & 6 \\
\hline \multirow[t]{2}{*}{ PROCESS } & Question-answer-oriented & 10 & $\begin{array}{l}\text { Instruction, explanation, } \\
\text { clarification }\end{array}$ & 9 \\
\hline & $\begin{array}{l}\text { Language-oriented development } \\
\text { generally not deliberate }\end{array}$ & 9 & $\begin{array}{l}\text { Language-oriented development } \\
\text { generally not deliberate }\end{array}$ & 9 \\
\hline
\end{tabular}

\subsection{Reflective Interviews}

3.1.1 Subject and Purpose of Participants’ Language-Oriented Development, Lesson 1

The results of the reflective interviews directly after lesson 1 (Table 4, first column) showed that the subject and purpose were generally intended to promote student understanding (8 out of 11 cases) through the clarification of subject-specific content (11 of 11) in response to questions that arose during a teacher's instructional explanation or clarification (10 of 11): 'learning to make connections between the content of different chapters' (P1)(note 1) and '[checking] whether students understand the material and are able to explain it' (P4). In this context, a distinction was made between teachers' and students' purposes: 'providing clarification' and 'paying attention, understanding and articulation of the issues at stake', respectively.

From me, it is expected that I ensure clarity. Students are expected to try to understand the question, to put their thoughts into words, to pay attention when I explain, to try to understand the issues and to eventually ask questions for clarification (P11).

\subsubsection{Process of Participants' Language-Oriented Development, Lesson 1}

The process was, according to the participants, regarded mainly (10 out of 11 participants, Table 4 , first column) as a form of question-answer learning conversation. In this context, a language-oriented response began with a teacher-generated demand, preceded by the introduction of theory and followed by students' response: 'through my questions, I expect students to explain the idea of variability in science' (P3). Conversely, in certain situations, the demand was generated by the students and followed by the teachers' response: 'The theoretical definitions raise questions from students; the teacher answers. I provide the space and help them to refine their understanding' (P2). In both cases, language-oriented development was generally not considered a deliberate activity (9 of 11) but was rather regarded as occurring after and resulting from teacher-initiated instructions or explanations (Table 4, first column).

\subsection{Stimulated Recall Interviews}

\subsubsection{Process Aspects of Participants’ Language-Oriented Development, Lesson 1}

The results of the stimulated recall interviews one week after lesson 1 showed that language-oriented development was generally ( 9 out of 11) not regarded as a deliberate and autonomous activity (as also indicated in the reflective interviews) (Table 4, first column). 
Table 5. Results of the Process Aspects of Language-Oriented Development, Lesson 1

\begin{tabular}{llllll}
\hline Self-Assessments of Process Aspects & & & & \\
Sufficient (S)/Deliberate (D) & S/ & P & NS/N & P \\
Not Sufficient (NS)/Not Deliberate (ND) & D & & D & \\
\hline 1. Starting and ending points & D & 2 & ND & 9 \\
2. Contingency on student language & S & 4 & NS & 7 \\
3. Deliberate use of question types & S & 0 & NS & 11 \\
4. Subject-specific key words and concepts & S & 8 & NS & 3 \\
5. Language-oriented feedback and support & S & 4 & NS & 7 \\
6. Language-oriented role model nonverbally & S & 5 & NS & 6 \\
& verbally & S & 3 & NS & 8 \\
7. Potential for improving LOP & S & 4 & Ns & 7 \\
\hline
\end{tabular}

\subsubsection{Starting and Ending Points and Degree of Contingency (Table 5: 1, 2)}

Nine out of 11 participants indicated not deliberately starting or finishing, and 2 of 11 noted that they finished only in a deliberate manner. With regard to whether teachers' instruction was contingent on student language, i.e., if it was responsive to the current level of the student, 7 out of 11 reported no sufficient contingency because of the regularly occurring confusion about interpretation and questions; 4 of 11 indicated a sufficient contingency, which was attributed to structuring factors such as the tempo used, sentence construction and word choice.

Examples of not deliberately beginning or ending language-oriented development are as follows: 'not preparing for specific forms of interactive practice' (P1) and 'being guided by what emerges' (P11). Participants also mentioned 'forgetting to summarize or evaluate at the end' (P6) or having a loss of focus or concentration due to other requirements during class:

The moment of interaction is diluted at the classroom level because I'm busy at an individual level with a student who asks me something that is not reproducible or comprehensible for everyone else (P7).

Examples of the conduct of non-contingent interaction concerned 'not listening carefully enough' (P6), resulting in situations in which student questions were interpreted incorrectly, and 'impatience', resulting in situations in which 'student responses were truncated' (P4). According to these participants, such situations could lead to a 'loss of control' (P2) or a 'temporary deadlock that may occur in lieu of an exchange' (P2). Others in the group (5 out of 11) attributed a sufficient degree of the contingency to factors such as the tempo used, sentence structure and word choice: 'Pauses between sentences' (P11); 'being concrete and using easy words' (P1); and 'answering questions in different ways, adapted to the comprehension level of the students' (P7).

\subsubsection{Deliberate Use of Question Types (Table 5: 3)}

All participants (11 out of 11) indicated that they either intentionally or unintentionally used a variety of question types as presented during the interviews, such as open and closed questions, leading questions, rhetorical questions or other questions that promoted higher-thinking skills, including reproduction, analysis or interpretation questions. Among this group, 7 participants noted that they use mainly open and closed questions, 2 suggested applying different types of listening skills during interaction, 1 reported intentionally limiting himself to open and functional questions to avoid wasting time, and 1 indicated that he does not ask any questions himself but allows the students to ask questions.

The examples given for the failure to use a variety of questions (10 out of 11) were attributed to a perceived lack of time and little or no awareness of different question types and how to apply them. Among this group, 8 participants reported using mainly open and closed questions: 'as far as I handle questions, because there are too few of them, I use open and closed questions' (P10) and 'Mainly open questions, such as asking for personal examples so that they know what it is about' (P7). Two participants suggested that they apply different types of listening skills during interactions: 'Yes, summarizing, ongoing questioning, confirming' (P8) and 'I probably should do more with paraphrasing and so on, and in doing so, give the ball back to the students or ask another student to continue what a former student said' (P2). One of the participants noted that he intentionally limits himself to open and functional questions to avoid wasting time: 'especially open questions, because I need the results for the rest of the explanation, not wanting to lose any more time, having to figure it out myself on my calculator and allowing the momentum to disappear' (P11). The participant who said that he did not ask any questions himself but left it to the students 
explained as follows: 'No, not usually, and in this fragment certainly not. The only questions are asked by the students; I do not encourage it myself' (P5).

\subsubsection{Subject-Specific Key Words and Concepts (Table 5: 4)}

Eight out of 11 participants indicated that they sufficiently address subject-specific key words and concepts. One of these participants emphasized his interest in frequent use, whereas 7 of the participants expressed some doubt about using this approach too often. Participants were generally satisfied with their method of employing subject-specific key words and concepts. Their views ranged from one participant emphasizing interest in frequent use- 'because it was explicitly intended to verify what students understood of the concepts, such as identity' (P11) and 'Yes, such as soil areas, chemical and physical fertility, nutrients versus workability' (P10)—-to another participant expressing doubt about using subject-specific key words and concepts too often: 'maybe even too much. Her question was much more concrete than my answer. They just wanted to know if what they said was good, and then I come with some abstract answer about how certain things should be' (P9). Participants' examples of employing subject-specific key words and concepts in a sufficient manner indicated their different ways of following students' experience, as indicated in the following excerpts:

Start from simple examples, and maybe then, slightly earlier, use even more words actually and check through audit questions for whether or not the concepts are clear to the students (P1).

Using questions from students to determine the level of knowledge and clarify concepts. I go deeply into these questions and use them to clarify other aspects of trigonometry (P8).

Language-Oriented Feedback and Support (Table 5: 5)

Seven out of 11 participants indicated that they do not efficiently provide feedback or guide students with linguistic expressions and formulations to encourage them in their language-oriented learning and formulation.

The explanation for not providing sufficient language-oriented feedback and support was, according to the participants, that this practice largely fell outside the area of their language-specific knowledge, as they were subject-specific teachers rather than language teachers:

What hinders me are two things: a) It is not in the field of my interest area, and b) I focus on the main goal of my class, which is transferring mathematical knowledge, understanding and skills in a short time (P11).

In this context, implicit and explicit forms of feedback were distinguished. Implicit forms included providing time for students to talk (P1, P3, P10, P7); thinking aloud along with students while they are thinking (P4, P9, P8); repeating students' statements in the teacher's own, and more appropriate, words (P11, P2, P6); and adjusting and simplifying the teacher's own choice of words and sentence structures 'down to a level where the concept can perhaps be understood' (P5). Explicit forms included providing language-oriented feedback on how students formulate and, when problems arise, correcting and supporting them, for example, by creating ' $a$ word web so given comments become more visible' (P9).

\subsubsection{Verbal and Nonverbal Language-Oriented Role Models (Table 5: 6)}

Eight out of 11 participants noted that they do not act as a role model verbally, and 6 of 11 noted that they do not serve as nonverbal role models. Regarding the majority ( 8 of 11) who reported not sufficiently acting as a role model verbally, the examples given concerned ways of using listening skills for repeating, asking questions, paraphrasing, summarizing and responding in the affirmative: 'whenever a student says something or asks in this excerpt, I repeat what he says, so the rest of the class can follow it' (P8); 'I see that I am affirmative in words. I put her at ease, and eventually, she talks openly' (P11); and questioning and summarizing what was said by a student (P10). Those who do not sufficiently act as a role model nonverbally reported that they did not deliberately and explicitly address regulatory skills in appropriate ways: 'I drop silences, so there is some space for thinking' (P10); 'When I ask the class for a recent example and there is no reaction coming, I bend forward and show visible interest in what is said' (P7); 'I am standing and I am walking almost constantly back and forth with my face to the classroom. I believe my posture exudes openness: openness for input of the students' (P8); and 'I do my best to show empathy for their situation' (P6). Regarding the other, smaller group of participants who reported that they do sufficiently act as a role model verbally, the participants mainly referred to their own mode as being largely dominant and sender-oriented: 'listening but also responding too quickly' (P1); 'constantly talking too much myself ' (P4); 'cutting off comments too quickly and not letting them reply'(P3); and 'providing the answers and solutions myself instead of asking them and having the students thinking themselves' (P9). With respect to serving as a role model nonverbally, participants referred mainly to using body language and gestures in an unaware or ineffective manner: 'Sometimes my body 
radiates passivity, bending slightly forward, expectantly, expressing something like "is there yet any reaction or not?"' (P1); 'The truncation of student responses is largely non-verbal through a stop sign with my hands and a raised voice, going over their head' (P2); and 'I was not well prepared and therefore radiated some anxiety or uncertainty. This is not a good example for future teachers' (P5).

\subsubsection{Potential for Improvement (Table 5: 7)}

Seven out of 11 participants reported not being actively engaged in their own language-oriented development. Most examples showed unused potential regarding language-oriented and reflective means of formulation in response to students' reactions. Specifically, concerning their needs, expectations or knowledge, two participants indicated that they had no room because of time or a lack of desire to address the issue: 'speed ensures that I literally do not stop at the thought' (P1). The other four participants referred to the ability to switch, in a flexible and creative way, between content-oriented pedagogy and the related language approach and, by doing so, adjusting the formulation or interaction accordingly depending on the present need: 'when you show interest, you engage students more easily, and you can jointly create anything' (P7) and '[you need] to listen carefully and to determine which subject matter and language-oriented targets you want to achieve'(P9).

\subsection{Comparing Reflective and Stimulated Recall Interviews}

\subsubsection{Participants’ Evaluation of Their Language-Oriented Development, Lesson 1}

Based on the results of participants' evaluation during both reflective interviews, directly after the first lesson - before the selection and consultation of participants' selected excerpts on video and the stimulated recall interviews - and one week later, while reviewing the selected excerpts on film, the general level of contentment with language-oriented development was adjusted.

Based on the results of the reflective interviews, 8 out of 11 participants indicated that they were satisfied with their overall performance during lesson 1 . This statement concerned their first reaction before consulting the selected recordings. The three participants who were not satisfied indicated that their teaching was 'going too fast' (P1) and that the 'pace was too high' (P2). Regarding their own lack of verbal and non-verbal communication, the following comment was offered: 'I am busy using too many stopgaps such as, yes, yes. I also repeat too many questions' (P4). In the first group, one participant reported being very satisfied because 'there was a lot of interaction with and between the students. I gave time and space to let them express themselves' (P8). The other seven also indicated that they were generally pleased with the 'opportunity for interaction' generated in their classrooms, but they considered the actual entry into and engagement in an interaction too limited: 'In general, I am talking too much' (P3) and 'it would have been better to sometimes ask a counter-question'(P4).

Table 6. Results of the Assessments of Language-Oriented Development, Lessons 1 and 2

Analysis of Interviews (Most Frequently Mentioned out of 11 Participants)

\begin{tabular}{|c|c|c|}
\hline Reflective & Stimulated Recall & Focus Group \\
\hline LESSON 1 & LESSON 1 & LESSON 2 \\
\hline Satisfied & 8 Satisfied & Satisfied \\
\hline Not Satisfied & 3 Not Satisfied & Not Satisfied \\
\hline $\begin{array}{l}\text { General lack of awareness } \\
\text { with regard to one's own } \\
\text { verbal and nonverbal } \\
\text { communication; } \\
\text { Countering and verifying } \\
\text { questions too little; } \\
\text { Unilateral focus and } \\
\text { teacher-sender orientation }\end{array}$ & $\begin{array}{l}\text { Perceived lack of } \\
\text { structuring skills and } \\
\text { opportunities to shape } \\
\text { targeted interaction; } \\
\text { Focus on content at the } \\
\text { expense of interpersonal } \\
\text { attention and relational } \\
\text { aspects }\end{array}$ & $\begin{array}{l}\text { Preparation of preferred language-oriented } \\
\text { goals and methods; } \\
\text { adaptation to language level through the } \\
\text { development of mutual understanding; } \\
\text { Change in teaching perspectives where } \\
\text { language-oriented development is not left to } \\
\text { the end but used as a means to achieve } \\
\text { common knowledge }\end{array}$ \\
\hline
\end{tabular}

Based on the results of the stimulated recall interviews, 9 out 11 participants reported not being satisfied, and two reported being satisfied. For the first group, the negative assessment was based largely on recordings that showed, according to the participants, a lack of an adequate response, i.e., not using 'targeted and structuring' methods in 
combination with 'interpersonal aspects in an appropriate manner' to invite students into subject-specific conversations in some cases. In this context, a predominantly sender-oriented teacher mode was considered one of the main reasons: 'not only talking too much but to also coming up with answers too quickly to my own questions without sufficient attention to what students say or do' (P4) (Table 6).

\subsection{Focus Group Interviews}

3.4.1 Subject and Purpose of Participants’ Language-Oriented Development, Lesson 2

Based on the results of the focus group interviews after lesson 2, the conversation content generally concerned 'subject-specific concepts' with the aim of having 'interaction and dialogue on subject-specific concepts and knowledge exchange from an interpersonal perspective to achieve subject matter and language-oriented targets': 'by your attitude, when you show interest, you engage students more easily, and you can jointly create anything' (P7). In this context, it is important for teachers 'to listen carefully and to determine which subject matter and language-oriented targets you want to achieve in advance' (P9) and to name 'content, form and process aspects or else the what, how and when' (P10) (Table 7).

Table 7. Results of the Focus Groups

\begin{tabular}{lll}
\hline Topics & Results (Most Frequently Mentioned out of 11 Participants) & \\
\hline \multirow{5}{*}{ SUBJECT } & LESSON 2 & 8 \\
& Subject-specific concepts & 3 \\
PURPOSE & Subject-specific content & 9 \\
& Content and concept explanation and clarification & 8 \\
& Interaction and dialogue on subject-specific concepts & 6 \\
& Knowledge exchange from an interpersonal perspective & 6 \\
\multirow{3}{*}{ PROCESS } & Achieving subject matter and language-oriented targets & 7 \\
& Teaching through language-oriented dialogue and debate & 6 \\
& Creation of knowledge, actively and jointly & 6 \\
\hline
\end{tabular}

\subsubsection{Process of Participants’ Language-Oriented Development, Lesson 2}

The process was, according to participants, generally driven by ‘deliberate and targeted action' based on a changing perspective on teaching (Table 4): 'as a teacher, you have to be an example and show a focus for direction in substance as well as in technical form because you do not have to be the know-it-all. That's a common misconception' (P3). According to this view, knowledge develops because of collective engagement in conversations instead of the all-knowing teaching of the teacher (Table 7).

Maybe it was a fixed idea to think that students have to understand it first, so I do the explaining part and then offer them all concepts before we can enter an interaction, if there is still time, and not vice versa. The interaction is saved for last because of that view, the time constraints and perhaps also because of the fixed idea that the main task of a teacher is to literally deliver something rather than to collectively and actively engage in conversation through which knowledge is acquired (P5).

The examples that participants gave of subject-specific teaching contexts in which students were invited to interactively engage were built on their identification with the subject to be addressed: 'the presence of a wooden bike that I posted in front of the classroom immediately caused more interactivity' (P4) and 'By asking for their idols, such as John Travolta, I used an example from their context in order to achieve higher thinking and abstraction levels' (P11). This approach, aimed at the active and joint creation of knowledge through language-oriented dialogue and debate, was, according to participants, a result of changing perceptions about teaching, whereby interaction was not left as the last activity but was used actively as a means to achieve common knowledge.

\subsubsection{Evaluation of Language-Oriented Development, Lesson 2}

Seven out of 11 participants indicated being positive about their language-oriented development based on structural, educational, verbal and relational aspects. Because of an expanded degree of self-awareness, aspects that were assessed less positively were related primarily to nonverbal aspects such as gestures and presence and other related manifestations. 
Verbally, I am doing fine, an open attitude with humor. Non-verbal is not good, not completing sentences, searching for words, and then it fades away. While talking. I am too aware of what I want to say, because of which I'm always doubting and nothing runs smoothly. When I'm thinking about my language use and what I want to say, I sometimes lose my words, especially when I start thinking about using difficult words. Then, my sentence stagnates because I'm thinking. I notice this even more when watching the film, so this probably happens even more often than I thought (P5).

I recognize in your snippet that you begin a sentence and do not exactly know how that ends. I also did see this with XX; he stops abruptly in the middle of a sentence and then goes on to another topic. With me, I usually go down in volume and start to mumble something. You know it, but you do not know how to let it come out naturally, let alone how to formulate it in a reasonable sense (P4).

The following reasons for positive assessment were indicated: better preparation regarding preferred language-oriented goals and methods for the exchange of key concepts, as well as the adaptation and cultivation of language levels through the development of mutual understanding (Table 6). Participants distinguished between professional learning and teaching when evaluating their own responses. Participants who reported not being satisfied with language-oriented learning characterized this form of learning as 'limited, still in an unconscious and initial phase' (P6). Participants who indicated that they were satisfied related this perception to the development of sensitivity and intuition toward language, aiming to promote understanding between themselves and students regarding concepts and terminology through which 'ideas are clarified and more systematically considered' (P7). Two participants who reported being satisfied attributed this result to their more targeted focus on student contributions and the clarification of the concepts and the thread of the argument. The three participants who expressed that they were fairly satisfied with their own language-oriented actions indicated that they did not explore actions focused on developing linguistic interaction with students because of their primarily content-oriented educational vision. In addition, a lack of confidence and time constraints affected their own language skills, which therefore resulted in a 'monotonous, boring, not interactive, subdued performance' (P5). Participants who reported being satisfied characterized their language-oriented development as a new awareness of questioning techniques and consulting opportunities in relation to the subject matter and, hence, being better able to act on what a 'full interaction requires' (P10). The interaction skills were identified as follows: 'intervene occasionally', more 'consideration of when to address issues and when not' (P7) and 'sharing one's own experiences on the impact of language and language use' (P6).

\section{Discussion and Conclusion}

In this section, by reflecting on participants' self-evaluation during the three interview stages, teacher educators' understanding of their language-oriented development is discussed.

\subsection{Evaluating Language-Oriented Development}

The results of the reflective interviews showed that a large majority of the participants were satisfied with the general approach of their language-oriented development. However, the results of the stimulated recall interviews showed that, one week later, they usually assessed their language-oriented development as 'not satisfied'. The first assessment, which occurred during the reflective interviews, was based on participants' immediate recall of relatively frequently occurring situations of academic dialogue. This outcome was based on an alleged situation of interaction. In this phase, language-oriented development was thus subjectively linked directly to interactive practice. Participants mentioned many opportunities for interaction and, thus, for language-oriented responses. The participants' examples showed that in this phase of assessment, a degree of uncertainty about the equivalence of input arose between the teacher and students because the situation was controlled, according to participants, by a teacher-as-sender-oriented mode. This outcome corresponds to the results of a recent study on the practical knowledge of language (Swart et al. 2017), in which sender-oriented teacher educators appeared to have more difficulty accepting the importance of student-teacher interaction. Other studies have shown that cycles of contingent interaction appear less frequently than unfinished, non-contingent cycles (Ruiz-Primo and Furtak, 2006, 2007) because of the lack of a common problem or diagnosis initiated by the teacher during observed teacher-student interactions (Elbers, Hajer, Jonkers, Koole, and Prenger, 2008; Lockhorst, van Oers, and Wubbels, 2006).

The second assessment, which occurred during the stimulated recall interviews, was based on the observed cases of interaction. Based on their direct observations, participants reported less interaction than they had previously reported during the reflective interviews. In addition, the interaction that occurred was generally more regulatory in nature than subject-specific. In this phase, language-oriented development was not directly linked to the presence or 
absence of interactive practice but was more strongly regarded as a spin-off of instruction and, in that capacity, as a precondition for generating interactive practice-for example, by asking different types of questions or by giving space for students' language-oriented reactions. These findings build on specified practical strategies for teachers' third turn responses (Nassaji and Wells, 2000). According to these authors, if a teacher implements further efforts beyond a solely evaluative mode, such as requesting explanation or meta-talk, students can be expected to self-select contributions because of a shift in the teacher role from the knowing sender to an initiating and evaluating role through which knowledge is developed in consultation with students. Furthermore, we found that participants' indicated interactions appeared to stimulate unfamiliar language-oriented methods for improving their own teaching, although the actual interaction occurred for different and often coincidental reasons. In addition, studies have claimed that students need learning experiences in which academic concepts are not only explained but also represented, communicated and validated by the teacher through argumentative stimulated interaction (Sampson \& Blanchard, 2012). For this reason, teacher educators must be more aware of the significance of the evaluation and the construction of knowledge (Suh and Park, 2017) and therefore create openings for interactive practice to build rationalizations and to exchange the intersubjectivity of each explanation at the same time. This approach also pertains to the means by which, according to participants, the interactive processes within their lessons interacted with their individual language-oriented development. For example, reflecting on student learning through interaction enabled the participants to move beyond their preconceived views about their own practice.

The process of language-oriented development during lesson 1 was regarded primarily as a question-answer dynamic that was initiated either by the teacher or by the students and typically not considered a well-prepared, autonomous and purposeful activity. Most examples illustrated common confusion in class about student interpretations of teachers' formulations because of untapped potential regarding teacher strategies for collaborating in a language-oriented and reflective manner in response to student comments and questions. This perception was the result of a self-perceived lack of contingent teaching, including little or no awareness of the basic conditions and capabilities, such as beginning and ending points, the potential for various question types and other reactive strategies. This outcome is in line with recent empirical studies showing that teachers are unable to act contingently (Van de Pol, Volman and Beishuizen, 2010) despite their typical position of understanding a student's request (Lee, 2007) using a variety of appropriate reactive strategies (Nassaji and Wells, 2000). Most participants indicated a desire to present themselves as good role models in language-oriented processes but had little idea of how to behave as such. A minority (four) of the participants mentioned that language-oriented potential referred to the ability to switch between content-oriented pedagogy and a related language approach and, thus, to adjust their language-oriented development depending on students' needs.

The participants generally assessed the process of language-oriented development during lesson 2 as deliberate, autonomous and purposeful through the use of language-oriented dialogue and debate. In terms of educational, structural, verbal and relational aspects, a majority of participants provided positive responses based on a modified conception of teaching. Aspects that were assessed less positively were related primarily to nonverbal aspects because of increasing forms of self-awareness, together with a lack of confidence in alternative language-oriented values and related education tools. From the participants' altered perspective on teaching, subject-specific knowledge develops because of collective engagement in dialogue. The mutual understanding emerging from this engagement can be subsequently achieved through the improved preparation of preferred language-oriented goals and methods adapted to students' comprehension levels. Earlier research (Keys, Hand, Prain, \& Collins, 1999) demonstrated that for teachers to change their fundamental principles and teaching strategies, they first need to shift their epistemological orientations toward student-centered views (Hand, 2008). This finding confirms Guskey's (2002) argument that teachers must observe the positive effect of new teaching strategies in order to make and sustain changes. Noticing a positive effect on student learning can, according to Suh and Park (2017), reinforce these changes in the orientation and acceptance of a new approach.

These results confirm our hypothesis that awareness of the importance of language-oriented development in content-based classroom interaction leads to a conceptual change in teacher educators and, thus, to reflection, new knowledge and new behavior, which may in turn lead to further awareness and to improved language-oriented teacher performance.

4.2 How Do Teacher Educators Understand Their Language-Oriented Development in Content-Based Classroom Interaction?

The purpose of language-oriented development after lesson 1 was generally perceived as teacher instruction and the transmission of subject-specific content to promote students' understanding of subject matter. After lesson 2, the 
purpose was regarded largely as a form of common knowledge exchange of subject-specific concepts from an interpersonal perspective to achieve both subject matter and language-oriented goals. The differences in purposes between lessons 1 and 2 can be explained by the three factors used to improve teacher learning: task control, stimulated recall and interaction in small groups. When beginning lesson 1, participants were instructed to teach a regular class without specific preparation or assignments related to their language-oriented responses. Between lessons 1 and 2, they actively participated in reflective activities through task control, stimulated recall and interaction in small groups. Thus, participants were more informed and more specifically involved in framing language-oriented aspects. In this context, two points can be made: lesson 1 aimed mainly at instructing the subject-specific content and directly related terminology of the profession. Lesson 2 was directed at the exchange of subject-specific concepts to learn the subject matter, achieve language-oriented goals and develop common knowledge simultaneously. In the first lesson, language-oriented development was thus primarily considered a means of talking (instead of interacting, which occurred in lesson 2) about subject matter through the use of language itself. These outcomes are in line with previous research, where participant-oriented engagement in subject-specific classrooms included interactions among students to not only promote students' learning of content but also to advance their use of language and their direct involvement. Consequently, developing learning and language becomes synchronized (Larsen-Freeman, 2013). In this context, language-oriented development can be considered not only a strategy that involves applying regulatory and explanatory language but also a pedagogy that connects academic and subject-specific knowledge with interpersonal-oriented language.

Finally, regarding the normativity that characterized the participants' professional practice, the premise that institutional forms and processes of teacher education generally frame how professionals should respond to the essential sociocultural processes of learning and teaching development is crucial to the outcomes of participants' language-oriented understanding in professional practice. As such, current teacher education practices establish our definition of what teacher professionalization entails. In this study, we argue that the core of a new language-oriented knowledge base must focus on the experience of teaching itself, i.e., it should center on the teacher educator who teaches, the contexts in which teaching occurs, and the pedagogy by which teaching is accomplished. Additionally, this knowledge base should include forms of knowledge representation that report teacher educators' professional learning development within the social and cultural contexts in which it occurs (Freeman and Johnson, 1998).

In conclusion, the results showed that the intervention changed the language-oriented development, which in turn affected the awareness of teacher educators and their decisions to improve language-oriented methods for initiation and response during class interaction. Based on the literature and our previous studies (Swart et al., 2017a, b), we assumed that teacher educators should be both language-sensitive and language-facilitating in order to provide accessibility and support through the convergence of interpersonal and pedagogically oriented language in content-oriented education. The results confirmed our assumption that the combined approach should be both language-sensitive and language-facilitating in order to develop a range of well-informed interactions in both an insightful and informative manner. For example, the teacher educators' identification process with regard to the subject, purpose, and process of their language increased both their language awareness and their pedagogical decisions about supporting and guiding learning conversations.

In order to further develop and improve the practical language knowledge of the teacher educators in content-based education, we consider that a framework is needed for language-oriented professional development. Such a framework for language-oriented professional development in content-based teaching and interaction requires a wider epistemological view of experienced teacher educators, namely one that accounts for teaching as it is applied and developed in professional learning. We propose that this approach will eventually lead to redefining how experienced teacher educators develop their continuous language-oriented professional learning in content-based teaching and classroom interaction

\section{Limitations and Directions for Future Research}

Because the findings of this study were drawn from the data acquired from eleven participating teacher educators, their generalizability is limited, but their transferability and application to different teacher educators and teachers in other contexts are certainly possible. We strived to provide a rich and full description of teachers' language performance that can be transferred to other similar teacher educators in similar content-related interaction contexts. Involvement in theorizing about the interaction of language and subject-specific content is currently receiving greater focus in teacher-training institutes. A goal is to conceptualize language and subject-specific content as separate entities rather than allowing them to be part of the same process in teacher educators' teaching. In addition to this concern about 
theory, there is a clear need for empirical research on teacher educators' practical language abilities by identifying their use of subject-specific language during interaction, particularly their strategy and intervention in various subject areas. This research should aid in clarifying what language-oriented and developing skills consist of and how they can be specified within specific subject areas.

On a theoretical level, this type of work should lead to a deeper understanding of teacher educators' language-oriented pedagogical subject knowledge and strategies. In particular, this strategy applies to teacher educators based on the following argument: when they are able to assess themselves and provide contingent and language-oriented feedback on student work, teacher educators act as role models for their students, who aim to be future teachers. Some teacher educators may find this strategy difficult to implement because they lack confidence in their students or because they habitually work from a teacher-sender mode (Nicol, 2010). This issue can be addressed by linking this contingent and language-oriented strategy directly at the beginning of interactive practice. For example, this link could involve including and inviting students to participate in structured forms of language-oriented feedback on the responses of both the teacher and each other. In this manner, the teacher educator gives feedback not only on the subject-specific content but also on the observations made by the students, allowing for a more equal and mutual appreciation of each other's linguistic and professional contributions.

\section{References}

Atkinson, P., \& Hammersley, M. (1994). Ethnography and participant observation. In N. K. Denzin \& Y. S. Lincoln (Eds.), Handbook of qualitative research (pp. 248-261). Thousand Oaks, CA, US: Sage Publications, Inc.

Bakkenes, I., Vermunt, J. D., \& Wubbels, T. (2010). Teacher learning in the context of educational innovation: Learning activities and learning outcomes of experienced teachers. Learning and instruction, 20(6), 533-548. https://doi.org/10.1016/j.learninstruc.2009.09.001

Boyd, M. P., \& Markarian, W. C. (2011). Dialogic teaching: Talk in service of a dialogic stance. Language and Education, 25(6), 515-534. https://doi.org/10.1080/09500782.2011.597861

Boyd, M. P., \& Markarian, W. C. (2011). Dialogic teaching: Talk in service of a dialogic stance. Language and Education, 25(6), 515-534. https://doi.org/10.1080/09500782.2011.597861

Boyd, M. P., \& Galda, L. (2011). Real talk in elementary classrooms: Effective oral language practice. Guilford Press. New York, NY 10012

Brinton, D., Snow, M. A., \& Wesche, M. B. (2003). Content-based second language instruction. An Arbor, MI: University of Michigan Press. https://doi.org/10.3998/mpub.8754

Coyle, D., Hood, P., \& Marsh, D. (2010). Content and Language Integrated Learning. Cambridge, United Kingdom: Cambridge University Press.

Dalton-Puffer, C., \& Smit, U. (2013). Content and language integrated learning: A research agenda. Language Teaching, 46(04), 545-559. https://doi.org/10.1017/S0261444813000256

Den Brok, P., van Eerde, D., \& Hajer, M. (2010). Classroom interaction studies as a source for teacher competencies: the use of case studies with multiple instruments for studying teacher competencies in multicultural classes. Teachers and Teaching: theory and practice, 16(6), 717-733. https://doi.org/10.1080/13540602.2010.517689

Echevarria, J., Short, D., \& Powers, K. (2008). Making content comprehensible for non-native speakers of English: The SIOP model. International Journal of Learning, 14(11).

Elbers E., Hajer M., Jonkers M., Koole T., \& Prenger J. (2008). Interaction in two multicultural mathematics classrooms: Mechanisms of inclusion and exclusion. In J. Deen, M. Hajer, T. Koole (Eds.), Interaction in two multicultural mathematics classrooms: Mechanisms of inclusion and exclusion. Aksant, Amsterdam (2008), pp. $141-172$

Eurydice Report. (2006). Content and Language Integrated Learning (CLIL) at school in Europe. European Commission. Retrieved Aug 2017 from http://www.eurydice.org/index.shtml

Freeman, D., \& Johnson, K. E. (1998). Reconceptualizing the knowledge - base of language teacher education. Tesol Quarterly, 32(3), 397-417. https://doi.org/10.2307/3588114

Glaser, B. G. (1965). The constant comparative method of qualitative analysis. Social problems, 12(4), 436-445. https://doi.org/10.2307/798843 
Guskey, T. R. (2002). Professional development and teacher change. Teachers and teaching, 8(3), 381-391. https://doi.org/10.1080/135406002100000512

Hajer, M. (2000). Creating a language-promoting classroom: Content-area teachers at work. Second and foreign language learning through classroom interaction, 265-286.

Hand, B., Cavagnetto, A., Chen, Y. C., \& Park, S. (2016). Moving Past Curricula and Strategies: Language and the Development of Adaptive Pedagogy for Immersive Learning Environments. Research in Science Education, 46(2), 223-241. https://doi.org/10.1007/s11165-015-9499-1

Herelixka, C., \& S. Verhulst (2014). Nederlands in het hoger onderwijs. Een verkennende literatuurstudie naar taalvaardigheid en taalbeleid. Den Haag: Nederlandse Taalunie.

Hoy, A. W., \& Weinstein, C. S. (2006). Student and teacher perspectives on classroom management. Handbook of classroom management: Research, practice and contemporary issues, 181, 222.

Keys, C. W., Hand, B., Prain, V., \& Collins, S. (1999). Using the science writing heuristic as a tool for learning from laboratory investigations in secondary science. Journal of research in science Teaching, 36(10), 1065-1084. https://doi.org/10.1002/(SICI)1098-2736(199912)36:10\%3C1065::AID-TEA2\%3E3.0.CO;2-I

Kyriacou, C., \& Issitt, J. (2008). What Characterises Effective Teacher Initiated Teacher-pupil Dialogue to Promote Conceptual Understanding in Mathematics Lessons in England in Key Stages 2 and 3: A Systematic Review: Report. EPPI-Centre.

Larsen-Freeman, D. (2013). Transfer of learning transformed. Language Learning, 63(s1), 107-129. https://doi.org/10.1111/j.1467-9922.2012.00740.x

Lacombe, J. (2014). Language in Use. Munich, GRIN Verlag. Retrieved from http://www.grin.com/en/e-book/278799/language-in-usehttp://www.grin.com/en/e-book/278799/language-in-us e

Law, J., Reilly, S., \& Snow, P. C. (2013). Child speech, language and communication need re - examined in a public health context: a new direction for the speech and language therapy profession. International Journal of Language \& Communication Disorders, 48(5), 486-496. https://doi.org/10.1111/1460-6984.12027

Lee, Y. A. (2007). Third turn position in teacher talk: Contingency and the work of teaching. Journal of Pragmatics, 39(6), 1204-1230. https://doi.org/10.1016/j.pragma.2006.11.003

Leech, N. L., \& Onwuegbuzie, A. J. (2007). An array of qualitative data analysis tools: A call for data analysis triangulation. School psychology quarterly, 22(4), 557. https://doi.org/10.1037/1045-3830.22.4.557

Lieberman, A., \& Miller, L. (2008). Teachers in professional communities: Improving teaching and learning. Teachers College Press.

Lincoln, Y. S., \& Guba, E. G. (1985). Naturalistic inquiry (Vol. 75). Sage.

Lockhorst, D., Van Oers, B., \& Wubbels, T. (2006). Dialogisch onderwijs en zelfstandigheidbevordering: Een onderzoek naar de praktijk van twee leraren. Pedagogische Studiën, 83(3), 191.

Lyster, R. (2007). Learning and teaching languages through content: A counterbalanced approach (Vol. 18). John Benjamins Publishing. https://doi.org/10.1075/lltt.18

Malterud, K. (2001). Qualitative research: standards, challenges, and guidelines. The lancet, 358(9280), 483-488. https://doi.org/10.1016/S0140-6736(01)05627-6

McLaughlin, M. W., \& Talbert, J. E. (2006). Building school-based teacher learning communities: Professional strategies to improve student achievement (Vol. 45). Teachers College Press.

Meijer, P. C., Verloop, N., \& Beijaard, D. (2002). Multi-method triangulation in a qualitative study on teachers' practical knowledge: An attempt to increase internal validity. Quality and Quantity, 36(2), 145-167. https://doi.org/10.1023/A:1014984232147

Mercer, N. (1995). The guided construction of knowledge: Talk amongst teachers and learners. Multilingual matters. Great Britain. Cromwell Press Ltd

Mercer, N. (2008). Talk and the development of reasoning and understanding. Human development, 51(1), 90-100. https://doi.org/10.1159/000113158

Mercer, N. (2010). The analysis of classroom talk: Methods and methodologies. British journal of educational 
psychology, 80(1), 1-14. https://doi.org/10.1348/000709909X479853

Mercer, N., \& Howe, C. (2012). Explaining the dialogic processes of teaching and learning: The value and potential of sociocultural theory. Learning, Culture and Social Interaction, 1(1), 12-21. https://doi.org/10.1016/j.lcsi.2012.03.001

Miles, M. B., \& Huberman, A. M. (1994). Qualitative data analysis: An expanded sourcebook. sage.

Moy, B., Renshaw, I., \& Davids, K. (2014). Variations in acculturation and Australian physical education teacher education students' receptiveness to an alternative pedagogical approach to games teaching. Physical Education and Sport Pedagogy, 19(4), 349-369. https://doi.org/10.1080/17408989.2013.780591

Nassaji, H., \& Wells, G. (2000). What's the use of 'triadic dialogue'?: An investigation of teacher-student interaction. Applied linguistics, 21(3), 376-406. https://doi.org/10.1093/applin/21.3.376

Nicol, D. (2010). From monologue to dialogue: improving written feedback processes in mass higher education. Assessment \& Evaluation in Higher Education, 35(5), 501-517. https://doi.org/10.1080/02602931003786559

Nikula, T., Dalton-Puffer, C., Llinares, A., \& Lorenzo, F. (2016). More Than Content and Language: The Complexity of Integration in CLIL and Bilingual Education. Conceptualising integration in CLIL and multilingual education, 101, 1.

Norris, J. M., \& Ortega, L. (2000). Effectiveness of L2 instruction: A research synthesis and quantitative meta analysis. Language learning, 50(3), 417-528. https://doi.org/10.1111/0023-8333.00136

Panday, R. G., Hajer, M., \& Beijer, J. (2007). Challenges in integrating academic and professional language competencies in the curriculum in Higher Education. [ICLHE 2006 Conference]. Pediatrics, 133(5), 1388-91.

Putnam, R. T., \& Borko, H. (2000). What do new views of knowledge and thinking have to say about research on teacher learning? Educational researcher, 29(1), 4-15. https://doi.org/10.3102/0013189X029001004

Rimm-Kaufman, S. E., Storm, M. D., Sawyer, B. E., Pianta, R. C., \& LaParo, K. M. (2006). The Teacher Belief Q-Sort: A measure of teachers' priorities in relation to disciplinary practices, teaching practices, and beliefs about children. Journal of School Psychology, 44(2), 141-165. https://doi.org/10.1016/j.jsp.2006.01.003

Ruiz-Primo, M., \& Furtak, E. M. (2006). Informal formative assessment and scientific inquiry: Exploring teachers' practices and student learning. Educational Assessment, 11(3-4), 237-263. https://doi.org/10.1080/10627197.2006.9652991

Ruiz - Primo, M. A., \& Furtak, E. M. (2007). Exploring teachers' informal formative assessment practices and students' understanding in the context of scientific inquiry. Journal of research in science teaching, 44(1), 57-84. https://doi.org/10.1002/tea.20163

Ryan, G. W., \& Bernard, H. R. (2000). Data management and analysis methods. In N. K. Denzin \& Y. S. Lincoln (Eds.), Handbook of Qualitative Research (2nd ed., pp. 769-802). Thousand Oaks, CA: Sage.

Sampson, V., \& Blanchard, M. R. (2012). Science teachers and scientific argumentation: Trends in views and practice. Journal of Research in Science Teaching, 49(9), 1122-1148. https://doi.org/10.1002/tea.21037

Saylag, R. (2014). An Exploration on the Silence in the Classroom within a Diagnostic Perspective: Whose Silence is this?. Procedia-Social and Behavioral Sciences, 114, 527-532. https://doi.org/10.1016/j.sbspro.2013.12.741

Scott, P. (2008). Talking a way to understanding in science classrooms. Exploring talk in school, 17-36. https://doi.org/10.4135/9781446279526.n2

Sharpe, T. (2008). How can teacher talk support learning?. Linguistics and Education, 19(2), 132-148. https://doi.org/10.1016/j.linged.2008.05.001

Skidmore, D. (2000). From pedagogical dialogue to dialogical pedagogy. Language and Education, 14(4), 283-296. https://doi.org/10.1080/09500780008666794

Smaling, A. (1994). The pragmatic dimension. Quality \& Quantity, 28(3), 233-249. https://doi.org/10.1007/BF01098942

Swain, M. (2000). The output hypothesis and beyond: Mediating acquisition through collaborative dialogue. Sociocultural theory and second language learning, 97, 114.

Swart, F., de Graaff, R., Onstenk, J., \& Knezic, D. (2017a). Teacher educators' personal practical knowledge of language. Teachers and Teaching, 1-17. 
Swart, F., de Graaff, R., Onstenk, J., \& Knèzic, D. (2017b). Teacher educators' conceptualization of ongoing language development in professional learning and teaching. Professional Development in Education, 1-16.

Suh, J. K., \& Park, S. (2017). Exploring the relationship between pedagogical content knowledge (PCK) and sustainability of an innovative science teaching approach. Teaching and Teacher Education, 64, 246-259. https://doi.org/10.1016/j.tate.2017.01.021

Swanson, H. L., Hoskyn, M., \& Lee, C. (1999). Interventions for students with learning disabilities: A meta-analysis of treatment outcomes. New York: Guilford.

Valeo, A. (2013). The integration of language and content: Form-focused instruction in a content-based language program. The Canadian Journal of Applied Linguistics, 16(1), 25.

Van de Pol, J., Volman, M., \& Beishuizen, J. (2010). Scaffolding in teacher-student interaction: A decade of research. Educational Psychology Review, 22(3), 271-296. https://doi.org/10.1007/s10648-010-9127-6

Vaughn, S., Gersten, R., \& Chard, D. J. (2000). The underlying message in LD intervention research: Findings from research syntheses. Exceptional Children, 67(1), 99-114. https://doi.org/10.1177/001440290006700107

Vygotsky, L. S. (1962). Thought and language. MIT Press, Massachusetts Institute of Technology. https://doi.org/10.1037/11193-000

Vygotsky, L. S. (1987). Thinking and speech. In R.W. Rieber \& A.S. Carton (Eds.), The collected works of L.S. Vygotsky, Volume 1: Problems of general psychology (pp. 39-285). New York: Plenum Press. (Original work published 1934.)

Walsh, S., \& Knight, D. (2016). Analysing Spoken Discourse in University Small Group Teaching. In: Creating and Digitizing Language Corpora (pp. 291-319). Palgrave Macmillan UK. https://doi.org/10.1057/978-1-137-38645-8_11

Wegerif, R., Boero, P., Andriessen, J., \& Forman, E. (2009). A dialogue on dialogue and its place within education. Transformation of knowledge through classroom interaction, 184-199.

Wells, G. (2001). Action, talk, and text: The case for dialogic inquiry. Learning and Teaching Through Inquiry. Teachers College Press, 2001.

Wells, G. (2006). Monologic and dialogic discourses as mediators of education. Research in the Teaching of English, 41(2), 168-175.

Wertsch, J. V. (1979). The regulation of human action and the given-new organization of private speech. The development of self-regulation through private speech, 79-98.

Wolf, M. K., Crosson, A. C., \& Resnick, L. B. (2006). Accountable Talk in Reading Comprehension Instruction. CSE Technical Report 670. National Center for Research on Evaluation, Standards, and Student Testing (CRESST).

\section{Note}

Note 1. A list of the codes used for participants is included in Table 1. 